\title{
Active vs. Passive Funds-An Empirical Analysis of the German Equity Market
}

\author{
Ernst J. Fahling1 ${ }^{*}$, Elmar Steurer ${ }^{2}$, Sven Sauer ${ }^{1}$ \\ ${ }^{1}$ International School of Management, Frankfurt am Main, Germany \\ ${ }^{2}$ Hochschule Neu-Ulm, Neu-Ulm, Germany \\ Email: *ernst.fahling@ism.de
}

How to cite this paper: Fahling, E. J., Steurer, E., \& Sauer, S. (2019). Active vs. Passive Funds-An Empirical Analysis of the German Equity Market. Journal of Financial Risk Management, 8, 73-91. https://doi.org/10.4236/jfrm.2019.82006

Received: April 5, 2019

Accepted: June 10, 2019

Published: June 13, 2019

Copyright $\odot 2019$ by author(s) and Scientific Research Publishing Inc. This work is licensed under the Creative Commons Attribution-NonCommercial International License (CC BY-NC 4.0).

http://creativecommons.org/licenses/by-nc/4.0/

\section{(c) (7) (5) Open Access}

\begin{abstract}
The purpose of this study is to capture value created by active funds in the German investment fund market. A sample of $n=194$ actively managed funds is investigated to assess relative superior or inferior performance. For each actively managed fund, percentage changes in closing share prices for various investment periods are recorded and together set against the performance of the passive market. A benchmark is created out of the arithmetic mean of four passive exchange-traded funds representing more characteristics of the market than the S \& P500 or DAX. Further bench-mark comparison is conducted with generally accepted Market Research Returns, and various performance calculation measures are presented. Risk-adjusted performance results show that active funds can and do create value in terms of abnormal returns, but these are mostly offset by expenses. Regression results prevent a rejection of the null hypothesis, indicating that active funds in general do not create significant value in form of alpha.
\end{abstract}

\section{Keywords}

Portfolio Decisions, Investment Decisions, Active Portfolio Management, Passive Portfolio Management, Performance Analysis

\section{Introduction}

This study assesses the performance of active and passive equity funds on the German market over a 10-year investment period. The scope of this research focuses specifically on actively managed equity funds and exchange-traded funds (ETF) which replicate equity indices and are from here on referred to as the passive benchmark.

The origin of the discussion of active vs. passive investment dates far back in 
history. Regarding outperformance analysis of active vs. passive equity fund investing, the findings are not completely congruent, although a large portion of studies conducted argue that in investing in passive funds will generally bring higher net returns than investing in active funds.

Participants of investing are profit-seeking investors who aim to understand the behavior of the stock market, and the efficient market hypothesis (EMH) is one attempt to describe it. The theory explores if and to which extent security prices reflect the available information to the market, i.e. the efficiency of the market.

The assumptions raised by Fama (1970) lead to three proposed forms of market efficiency as well as to the notion, that new information doesn't only cause price movements, but security prices in general should reflect all publicly available information. Therefore, investors earn returns in accordance to the level of risk of the security. A predominantly accepted perception regarding the substance and validity of the EMH paradigm is that the market is somewhat efficient, but not to the extent that the hypothesis claims.

Hence, many authors argue in support of a semi-strong efficient market, some of the notables are Basu (1977), Grossman \& Stiglitz (1980) and Sewell (2011). Malkiel $(2003,2005)$ insists on a completely efficient market, and on the other hand other groups advocate a weak form of market efficiency (De Bondt $\&$ Thaler, 1985; Chan, Gup, \& Pan, 1997; Schädler, 2018). Before this hypothesis was developed, it was commonly assumed that the logarithm of a security was the appropriate measurement of prices (Read, 2013), as well as past performance an indicator of future performance (Malkiel, 1995). The random-walk hypothesis was introduced in 1953 (Lim, Lim, \& Zhai, 2012). This theory proposes that share price movements are random and therefore no prediction of prices is possible, which is consistent with the ideology of efficient markets. A further issue raising the discussion of the EMH is the alleged existence of a real market portfolio reflecting the overall weighted market return.

The overall weighted market return consists of both active and passive funds, indicating that if the value of the market return is equivalent to the value of the passive funds' performance, then the market return must also be equivalent to the active sector (Sharpe, 1991). Generally, a passive investment strategy reflects the market portfolio in form of benchmark indices or index funds such as the DAX or the S\&P 500. Fuller, Han, \& Tung (2010) argue that there is essentially no passive investment management, and the common reference of the term is a misconception. The term passive indexing is suggested to be an uncostly type of diversified active management.

\section{Literature Review}

Most of literature suggests that active management exhibits inferior performance in comparison to passive funds. However, many authors have demonstrated that active funds can outperform the market, leaving the question unanswered as to 
which style shows superior performance.

There are four major themes identified in the literature, which are divided into investment period (up to 10 years and between 15 - 20 years), "hot-hands" performance persistence, geographic differences, and transaction and trading costs.

Regarding literature analyzing investment horizons of 10 years, research predominantly agrees on the superior performance of the passive market over this specific period. Grinblatt \& Titman (1989) examine holdings of mutual funds from 1975-1984 on a quarterly basis and utilize data to estimate risk-adjusted gross returns and to test for superior performance in mutual funds. Excess returns are regressed with a mean-variance benchmark, following the method commonly referred to as the Jensen Measure. The findings show that abnormal performance through active management exists, and this trend is especially observed in growth funds and funds with lower net asset values. The well performing funds exhibit the highest expenses, which offsets the abnormal returns and leaves no superior performance net of expenses.

Gruber (1996) conducted a ten-year study demonstrating similar results. 270 US mutual funds in the time period between 1984-1995 were evaluated and regressed with a four-index model. Actively managed funds in aggregate had inferior returns compared to the market portfolio return, which was also represented through a bond index. Inferior performance of active funds ranged from $-1.9 \%$ to $-0.6 \%$.

A further study analyzing the performance of mutual funds in a ten-year period from 1997-2006 was conducted by Blanchett \& Israelsen (2007). Active funds were divided into 9 different investment styles and three test populations were analyzed, namely the headcount of funds, weighted average of assets of funds, and distinct funds. Results showed that in all three test populations several fund types of active funds over performed in average relative to various indices. However, actively managed funds do not earn superior returns on a consistent basis.

In aggregate, passive market indices will earn superior returns. The over and underperformance strongly depends on the benchmark index applied, as the results from Brinson, Hood, \& Beebower (1995) demonstrate.

Fama \& French (2010) executed a more contemporary study to assess superior performance of active funds. Results demonstrated that active managers can exhibit higher stock picking skills to cover their management fees, and subsequently only the top deciles earn superior performance relative to the passive market. As other results demonstrate, active management can indeed outperform passive management. The empirical evidence of outperformance of active investing is not as strong as that of the opposing side. In one of the advocating studies, performance was not only estimated but attributed to investment decisions of portfolio managers. An econometric framework was developed to assess managerial skill and the relationship with mispricing of securities. The study links portfolio managers' beliefs, views and other parameters with the portfolios 
having the highest and lowest Sharpe ratios. Results suggest that active funds can be a higher performing alternative than passive indices when measuring performance with the Sharpe Ratio (Pástor \& Stambaugh, 2002).

When looking at longer investment horizons for periods of at least $15-20$ years, there are more favorable results regarding active funds generating abnormal returns.

Jensen (1968) conducted one of the first noteworthy academic analyses of performance of active vs. passive investment, which is still commonly cited in contemporary literature. It has created an academic discussion that is lasting to this day. In his study, the returns of 112 US mutual funds from 1945-1964 were examined. One aim was to determine active managers' predictive abilities anticipating price changes of securities given their level of risk. Regression results with a market portfolio equation showed that actively managed funds underperformed gross of management fees in contrast to the market portfolio. Merely one single fund observed performed superior resulting in a statistically significant alpha. This implies that even before accounting for management fees returns were lower than the market returns. Carhart (1997) conducted a thirty-year long study (1962-1993) and evaluated over 1800 mutual funds. Different fund types were analyzed and compared with a four-factor model.

Results showed that only the first decile of all actively managed funds earn high enough returns to cover management fees and expenses. Hendricks, Patel, \& Zeckhauser (1993) analyzed data over 15 years during the same time-period as Carhart, but their analysis tends to indicate superior performance through active management. Malkiel (1995) assessed only US equity mutual funds from 1971-1991 in two ten-year time horizons. The performance relative to the S \& P 500 and Wilshire 5000 index revealed that the indices had superior returns to the mutual funds in average. Wermers (2000) examined returns of over 1200 funds from 1975-1994 which were regressed with the CRSP value-weighted benchmark index.

Results show that mutual fund performance outperforms the benchmark yearly on average by $1.3 \%$. A noteworthy corporate study by Philips, Kinniry, \& Walker (2014) also advocates active investing. 2800 actively managed funds within an investment horizon of three decades were assessed to gain insights on the cyclicity of fund performance. In one of the three decades, $63 \%$ of all US equity mutual funds outperformed the market portfolio returns (Philips, Kinniry, \& Walker, 2014).

The suggested trend that active investments tend to generate abnormal returns over rather longer investment horizons is in alignment with evidence that there is a stronger correlation between the long-term performance of active funds and the outperformance of the passive indices (Malkiel, 2003).

Regarding the trading and management costs, literature presents the notion that active investors can outperform passive indices, but do not achieve that on a general basis due to costs (Shukla, 2004). Generally, there are very low costs when purchasing a passive ETF, whereas significantly higher costs when pur- 
chasing an actively managed fund. In addition, research data demonstrates that interim revision of a portfolio earns abnormal returns gross of expenses, but not net of costs, which also applies to results of a one-month holding period (Shukla, 2004).

Research has focused on the relationship between management costs and excess returns and identified a positive correlation, indicating the higher the costs the better the fund performs (Fama \& French, 2010).

Hence, a small proportion of active managers do indeed earn abnormal returns and therefore demand higher management fees, even though most academic researchers agree that investors are better off with passive indices than active funds simply due to outperformance.

Most studies conducted do not account for transaction and management fees, as they only investigate the gross performance of active funds. Grinblatt \& Titman $(1989,1992)$ and Womack (1996) account for costs in their studies, but do not empirically analyse the expenses. Carhart (1997) results suggest net performance is negatively correlated with costs. Wermers (2000) dismantles the returns of a sample of all equity funds free from survivorship bias and attributes the abnormal performance to stock-picking skills, trade-related costs, fund expenses, and the remaining difference between gross and net returns. The dataset merged from two databases, and the returns are recorded throughout 1975-1994. Regarding the methodology, a total of 6 measures are employed to attribute returns to each one.

Results show that stock-picking ability can compose $0.75 \%$ of abnormal returns. Furthermore, expenses and costs accounted for $0.65 \%$ of yearly returns at the beginning of the study in 1975 and increased to $0.99 \%$ in 1994. Malkiel (2003) also suggests that after costs active funds in general must underperform the market benchmark. Results of his study, which focuses on index investing and efficient markets, show that costs and expenses account for $1.2 \%$ of performance in average. Data in the study assumes a market return of $10 \%$, and these 120 basis points attributed to expenses from active investing are the exact thresholds which lead to underperformance relative to the benchmark.

\section{Methodology}

The approach of collecting share prices and performance data reflects a deductive and quantitative approach. Cross-sectional data has been collected consisting of active equity mutual funds' prices from publicly accessible financial websites and databases. The evidence and findings of the empirical analysis is presented through descriptive statistics, measurements, correlation, and ranking, which reflects a deductive data analysis.

For this empirical assessment, a hypothesis was developed which will assume a sample value of a population parameter to be true, and this assumption will be tested to assess if the statistical evidence indicates if the hypothesis is true or not. The null hypothesis $\mathrm{H} 0$ asserts the belief that alpha a, referred to as abnormal returns compared to the market, is equal to or less than 0 . Contrarily, the alter- 
native hypothesis expresses the notion that a is not equal to 0 . Thus, the null and alternative hypothesis can be expressed as the following:

$$
\begin{aligned}
& H_{0}: \mu_{\alpha} \leq o \\
& H_{1}: \mu_{\alpha}>o
\end{aligned}
$$

The sample of funds used for this research was obtained through a database from the German Federal Financial Supervisory Authority, also referred to as BaFin. This institution regulates and supervises all sectors of the finance system in Germany. Specifically, it governs asset management companies and their offered investment funds under the German Investment Code. The institution provides an online database of all open-end and closed-end investment funds available as exhibited in Investmentfonds-Datenbank. This database ${ }^{1}$ includes all publicly listed funds admitted for sale in the member countries of the European Union. 13,114 funds were exported and filtered to obtain only active equity funds for sale in Germany and Luxembourg, as well as funds defined as "single" funds excluding umbrella funds and funds consisting of company assets. In the German fund market (including Luxembourg), 8966 funds are available for sale, of which $77.6 \%$ are defined as non-EU OGAW and $15.7 \%$ as domestic OGAW. The other classes such as mixed investment assets, real estate and closed AIF funds, all have low single digit percentage share. By filtering out funds with irrelevant assets under management and funds that were incepted after 2007 and including only single funds available for sale in Germany and Luxembourg, a sample size of $n=194$ equity funds was obtained and used for the statistical performance measurement executed within the scope of this study, as presented in Figure 1. Regarding the fund type, all active mutual funds were divided into value, growth, income, industry, blue-chip, or other shares. Subsequently, the daily share prices of a 10-year investment period between 01/01/2007-12/31/2017 of all funds were considered.

The measurement of return is calculated as the closing price of the fund, expressed as the percentage of the share price at the beginning of the respective time periods, as presented in the following formula:

$$
R=\frac{C P_{t}-C P_{t-1}}{C P_{t-1}}
$$

where

$C P_{t}=$ Closing price of security,

$C P_{t-1}=$ Original closing price of security for preceding time period.

After the performance of all funds is recorded, the mean return based on daily, weekly, monthly, half-year and yearly price changes is calculated using the arithmetic and geometric return:

$$
\begin{gathered}
R_{\text {Mean }}=\frac{R_{M 1}+R_{M 2}+R_{M 3}+\cdots+R_{M n}}{N} \\
R_{G}=\sqrt[n]{R_{1} * R_{2} * R_{3} * \cdots * R_{n}}
\end{gathered}
$$

${ }^{1}$ https://portal.mvp.bafin.de/database/FondsInfo/. 


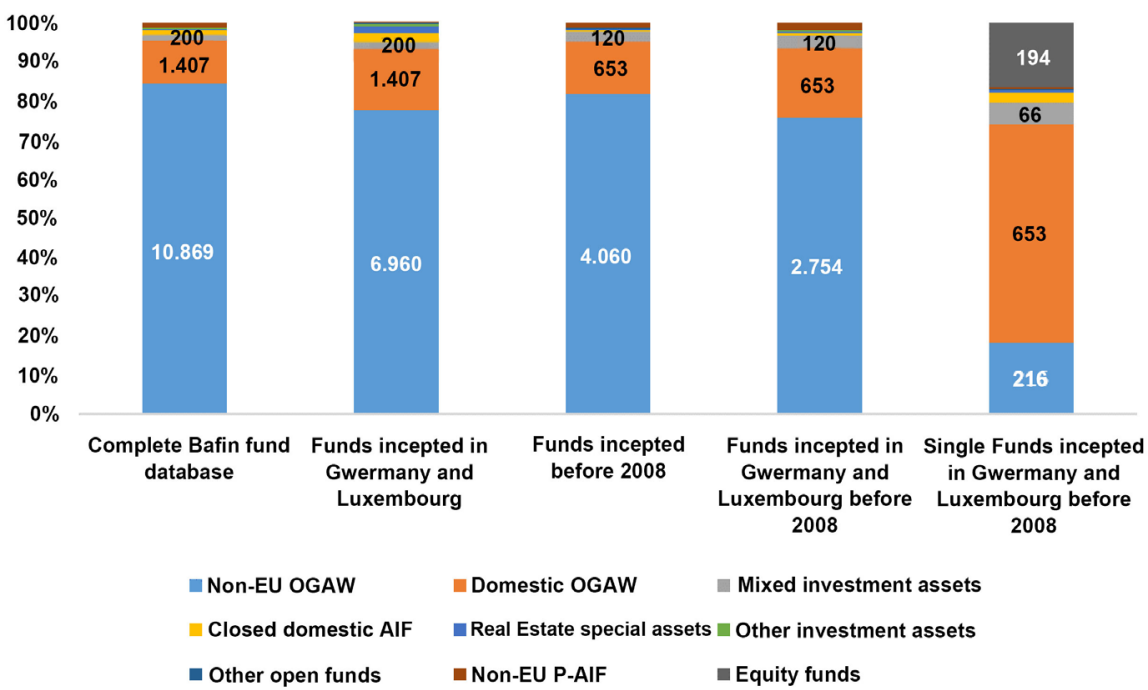

Figure 1. Overview of German fund market and funds used in this methodology. Notes: Figure 1 presents the distribution of the different kind of funds amid an overview of the German fund market. 194 single equity funds incepted in Germany before 2008 were used in this research. The other pillars show the market of funds used in the fund database from the Bafin.

where

$R_{\text {MEAN }}=$ Average returns per $\mathrm{n}$,

$n=$ Total number of time periods applied,

$R_{G}=$ Geometric return per $n$.

A further descriptive return measurement is the average annual return $(A A R)$, calculated as the net of yearly total expense ratio $(T E R)$. Subscription fees and transaction fees are not included in the $A A R$, which is expressed as the following formula:

$$
A A R=\sum_{K=1}^{n} \frac{R_{M Y n}-T E R_{Y n}}{N}
$$

where

$R_{M Y n}=$ Return per year $n$,

$T E R_{Y n}=$ Total expense ratio per year $n$.

Contrary to the mean returns, the $A A R$ is the calculated net of the $T E R$ for that year, and geometric and logarithmic returns are also identified.

It is inevitable to avoid biases in the selection and data analysis process of performance measurement of daily share prices over a longer time horizon. The first bias is a general issue in various types of research and data collection, but it is also an important process to account for in performance measurement. It is defined as survivorship bias and is also occasionally referred to as a selection bias. In general, it is the notion of accounting for the whole fund sample and not just for funds that "survived" due to superior performance. Often poor performing funds tend to close and disappear over time, since it becomes harder to distribute a fund with consistent inferior returns. Large fund management com- 
panies have the capability to merge poor performing funds into well performing funds.

Studies analyzing mutual funds generally use samples over 5 - 10-year time periods, sometimes even longer. During this time, funds tend to disappear either through poor performance, through merging with another fund, or because management decides to take it from the market because of too low fund value. Also, fund managers often launch several funds simultaneously of which knowingly only a few will remain existent. This technique is used in contemporary fund management to identify and retain the best performing funds while subsequently identifying the best performing fund managers (Malkiel, 1995).

The issue for this study is that these poor returns from the funds that closed or merged are not included in the database of BaFin. Many studies ignore the survivorship bias because it is so difficult to find data on closed or merged funds. Also, most databases and subsequently studies in the academic research employ data that are not survivorship bias free. Through independent research it is suggested that survivorship bias accounts for about $0.4 \%-0.6 \%$ of risk-adjusted yearly returns (Grinblatt \& Titman, 1989; Brown, Goetzmann, Ibbotson, \& Ross, 1992; Malkiel, 1995; Elton, Gruber, \& Blake, 1996).

A further bias that arises in studies done on returns and performance of funds is analyzing the wrong dimensional unit. Many studies show results in which the input parameters are the number of funds counted, but not the fund assets (Blanchett \& Israelsen, 2007). These studies don't put emphasis on actual asset-based analysis, and they therefore do not account for the size of each fund.

Researchers also must account for an additional bias when conducting studies on performance measurement, which is characterized as "one-year earnings momentum". Similar to having "hot hands", results of empirical studies tend to suggest even stronger persistency in the year after a manager enjoys abnormal returns, indicating strong evidence for one-year fund performance persistence (Carhart, 1997). Often this trend is observed at funds' inception where managers earn abnormal returns in two subsequent years, followed with lower returns in the successive years. If a trader who focuses on short-term price movements were to follow this theory, he or she should search for funds to invest in which exhibit superior performance in the previous year but should keep in mind that the returns are lower in the years following. In general, an adequate strategy to minimize the one-year's earnings momentum bias is to apply a multi-index model in the statistical analysis of the performance.

In this study, the sampling approach and data collection mitigates this bias to a certain extent. By including only funds with an inception date before 2007 in the analysis of this study, there are only a small insignificant number of funds that fall under this bias, namely the funds that were incepted in 2006.

Share prices obtained for this study disregard dividend payouts, capital gains or stock splits. Hence in calculating returns, this study treats all funds as the same type, irrespective of if they are distributing or reinvestment funds. Returns are calculated as the closing price of the fund, expressed as the percentage of the 
share price at the beginning of the time period chosen in this research, as Malkiel (1995) and Hendricks et al. (1993) do in their respective researches, e.g. with quarterly returns of the asset value of the fund.

Daily, weekly, monthly and yearly share prices for a ten-year investment horizon are assessed, contrary to most studies which generally calculate monthly or yearly performance. The most efficient method of judging the performance of an actively managed fund is to compare it's returns with the benchmark index. Without a comparison with the market return, it is not possible to make sufficient assessments of a fund's performance.

As Sharpe (1991) points out, a sound comparison for an active manager's performance is a comparable passive alternative. This alternative portfolio should be an attainable alternative identified before the performance of a fund is measured. Even though using an identified market proxy is the most efficient method of active performance measurement, it is only efficient in relative terms and not in absolute, because there is simply no feasible alternative to a market benchmark index. In reality, a portfolio of securities forming an index can never completely and fully reflect the overall market return. First, there is always a lag in timing when rebalancing the portfolio to reflect the market return. Also, as noted above, there is a mathematical restraint of the total number of securities in a fund, which also applies to the "market index" because it is structured as an ETF, which also holds the legal form of a fund. Most ETFs reflecting a market index do not even hold 64 positions. Fully emulating the "overall market returns" with a portfolio is therefore not realizable. But what really is the overall market?

Sharpe (1991) suggests that the total weighted market return costs of all returns in the market, meaning both active and passive funds. If both active and passive fund sectors contribute to the market return, then this would theoretically imply an index must be developed which reflects the market through already available passive indices, as well as all active funds. Most studies as well as analysts use commonly known indices as benchmark returns, such as the S\&P 500 , because it allegedly reflects a large portion of the overall market. This index does not account for small cap and value shares returns, which is why Fama and French's three-factor model is applied for performance measurement.

Regarding the benchmark comparison, a different approach was applied in this study. Four indices were chosen which aim to reflect the characteristics of the sample relative to the overall market. The indices chosen are the $\mathrm{db} \mathrm{x}$-tr., MSCI World Index ETF, Deka STOXXQR Europe Strong Value 20 UCITS ETF, Deka STOXXQR Europe Strong Growth 20 UCITS ETF, as well as the iShares EURO Dividend UCITS ETF. By choosing these four indices, anomalies such as value shares, growth shares, dividend shares and country allocation are minimized.

The market returns of all four indices are averaged and utilized as the overall market return. In addition, a further benchmark is applied independent of the four-index model to provide a broad range of results with different market returns. For this second benchmark, Kenneth R French's Research Factors of 
excess market returns are identified from his infamous website. Monthly returns are provided for the last 12 years. By applying two separately structured passive benchmarks, a broader opportunity to compare the returns is presented. Hence, relative performance of the active funds can be identified in more than one perspective, and a more detailed assumption of the real passive market return is established.

Due to the complexity of all kinds of different variables, influences, and external forces, no study can be completely free from bias, nor provide completely significant returns. Hence, this study also has certain limitations biases which aren't mitigated.

As mentioned in previous sections, one limitation of this study is accounting for the survivorship bias. Obtaining a completely survivorship bias free sample of funds is extremely difficult, as described. Even when adjusting returns with the estimated arithmetic value of the survivorship bias, a completely exact value will not be identifiable because each sample has a different degree of survivorship bias. The second limitation of this study is also unique to the sampling approach and data collection. As pointed out, there is a distinction made in the selection process of the funds regarding their structure. In Germany it is possible to launch single funds as well as sub-funds and umbrella funds. In the latter, the company's net assets equal the total of all sub-fund's net assets, whereas this is not the case for single funds. From the total population of available funds in Germany, more funds employ a sub-funds and umbrella funds structure.

For this research, only single funds are included in the data, which limits the findings of value creation of active funds. A further limitation results from the raw share price data. Even though several sources of publicly listed share prices were used and compared with each other, occasionally single-day share prices were not provided. One reason is that certain funds, although available for sale in Germany, are only listed on foreign exchanges, such as the Swiss Exchange. Since the exchanges have different opening and closing days than Germany due to different holidays, share prices from some days were missing. The only solution for the analysis and calculation was to use the closing price from the last day available. In total, the missing data is insignificant. There are over 2500 daily share prices for a ten-year investment horizon, and on occasion few of these were missing.

\section{Findings}

This section of the study will provide the findings of the empirical testing conducted. A performance comparison with the active funds' performance, the passive index created for this research, as well as French's Research Factor Market Returns is presented. All results presented are generally calculated gross of costs, not accounting for the Total Expense Ratio (TER), subscription fees, management fees and handling fees. The defined benchmark consisting of passive indices chosen for this study achieved an annualized mean return of $\mathrm{rp} 1=4.90 \%$ over the 10-year investment horizon. The Research Factor Market Returns, 
which are representative of the other proxy as a passive benchmark, recorded an annualized mean return of $\mathrm{rp} 2=3.99 \%$. The benchmark index developed for this study accounts for small cap and value share outperformance. If the SMB and HML factor is added to the returns of the first benchmark, there is no significant difference in the annualized returns of the two benchmarks. Furthermore, the correlation measure shows that both benchmarks show significantly similar share price movements. The tracking error, which measures the standard deviation of the differences of the two benchmarks, is relatively low at $1.19 \%$.

Table 1 presents the returns of all active funds analyzed in this study on a daily annualized and yearly arithmetic basis. The daily annualized holding period return of all active funds was ral $=5.47 \%$, which is computed by annualizing all daily recorded returns. The yearly arithmetic holding period return was ra2 $=5.09 \%$, and is computed by dividing the total holding period return through the number of years of the investment horizon.

In comparison, the active funds performed gross of costs superior relative to both benchmarks in terms of annualized returns as well as arithmetic and logarithmic yearly returns. Interesting to note is that the active funds achieved higher returns only on a 10-year cumulative basis.

Table 2 presents the alpha that active funds created over the complete investment horizon, defined as returns of passive funds deducted from returns of active funds. The alpha presented in this table is a measure of average holding period return and statistically insignificant. The empirical evidence shows that active funds generate value on a daily and a yearly basis but tend to be similar to passive funds on a weekly and monthly horizon. Table 3 shows cumulative returns, which comprises of the total holding period return of the active funds and the passive benchmark for five different time horizons. Again, the performance in this table is a measure of average holding period return and statistically insignificant. In terms of cumulative returns, the market outperformed the active

Table 1. Descriptive statistics of daily annualised and yearly returns for all active funds.

\begin{tabular}{ccc}
\hline & Daily returns & Yearly returns \\
\hline Arithmetic mean & $0.02 \%$ & $5.09 \%$ \\
Annualised arithmetic mean & $5.47 \%$ & - \\
Logarithmic mean & $0.01 \%$ & $2.23 \%$ \\
Annualised logarithmic mean & $2.59 \%$ & - \\
Median & $0.05 \%$ & $9.22 \%$ \\
Min. & $-11.43 \%$ & $-48.08 \%$ \\
Max. & $12.88 \%$ & $39.25 \%$ \\
Variance & $0.27 \%$ & $4.96 \%$ \\
Standard deviation & $1.45 \%$ & $21.31 \%$ \\
Annualised standard deviation & $23.02 \%$ & $21.31 \%$ \\
Kurtosis & 11.17 & 2.57 \\
Skewness & -0.03 & -1.30 \\
\hline
\end{tabular}


Table 2. Alpha of active and passive returns.

\begin{tabular}{ccccc}
\hline & Daily & Weekly & Monthly & Yearly \\
\hline Arithmetic mean & $0.00 \%$ & $0.01 \%$ & $0.03 \%$ & $1.23 \%$ \\
Annualised arithmetic mean & $0.57 \%$ & $0.45 \%$ & $0.38 \%$ & - \\
$\quad$ Logarithmic mean & $0.00 \%$ & $0.00 \%$ & $0.01 \%$ & $0.66 \%$ \\
Annualised logarithmic mean & $2.23 \%$ & $0.18 \%$ & $0.17 \%$ & - \\
\hline
\end{tabular}

Table 3. Cumulative returns of active funds and passive market.

\begin{tabular}{ccccc}
\hline \multicolumn{5}{c}{ Active funds } \\
\hline $6 \mathrm{~m}$ & $1 \mathrm{y}$ & $3 \mathrm{y}$ & $5 \mathrm{y}$ & $10 \mathrm{y}$ \\
$9.79 \%$ & $7.04 \%$ & $24.27 \%$ & $66.92 \%$ & $37.52 \%$ \\
\hline $6 \mathrm{~m}$ & $1 \mathrm{y}$ & Benchmark & \\
$11.95 \%$ & $13.49 \%$ & $33.42 \%$ & $76.26 \%$ & $35.21 \%$ \\
\hline
\end{tabular}

funds in all but a 10-year investment horizon. Cumulative return is equivalent to a buy-and-hold strategy.

The presentation of risk-adjusted returns follows a separate methodology in order to account for market risk, market returns or for the sensitivity of a share relative to market movements. Findings in Table 4 are based on various rankings with the intention to display a wide range of the best performing funds. Hence, the funds are ranked based on the average holding period return, Sharpe ratio, Treynor ratio, Information ratio and Jensen's alpha. Those funds that were noticeably present in all the mentioned rankings were chosen to be displayed in Table 4. The results show that among the rankings, there are three funds with a focus on 'biotechnology' in the list of the best performing funds. These funds are SEB Concept Biotechnology, Allianz Biotechnologie and apo Medical Opportunities. The classification between distributive and reinvestment funds was also insignificant, as both types are almost equally distributed amongst the best performing funds, as seen in (Table 4).

The average returns, standard deviation, and risk adjusted measures in Table 5 demonstrate how the different fund types performed. This table allocates all funds in various classifications and presents return, risk, risk-adjusted performance, and implied cost of equity. The latter is calculated on the basis of Fama and French's Three Factor Model, which is a complement of the CAPM and adjusts for the tendency that value and small cap stocks tend to outperform. When using the given variables of the average return, market premium, risk-free rate, and the HML and SMB premiums as input parameters in the formula, an implied cost of equity is calculated for each classification shown in this table, which is adjusted for the small cap and value stock performance bias. This is the measure that reflects the return investors of this fund expect, according to the model. 
Table 4. Risk-adjusted performance measures and rating analysis.

\begin{tabular}{|c|c|c|c|c|c|c|c|c|c|c|c|}
\hline \multirow[t]{2}{*}{ Name of funds } & \multicolumn{2}{|c|}{$\begin{array}{l}\text { Total average } \\
\text { return }\end{array}$} & \multicolumn{2}{|c|}{$\begin{array}{l}\text { Sharpe } \\
\text { ratio }\end{array}$} & \multicolumn{2}{|c|}{ Treynor ratio } & \multicolumn{2}{|c|}{ Information ratio } & \multicolumn{2}{|c|}{$\begin{array}{l}\text { Jensen's alpha } \\
\text { (non-regression) }\end{array}$} & \multirow[t]{2}{*}{ Type of fund } \\
\hline & Value & Rank & Ratio & Rank & Ratio & Rank & Ratio & Rank & Alpha & Rank & \\
\hline SEB Concept Biotechnology & $18.06 \%$ & 2 & 0.604 & 3 & 0.324 & 11 & -17.063 & - & -0.233 & - & Reinvestment \\
\hline $\begin{array}{l}\text { SEB European Equity } \\
\text { Small Caps }\end{array}$ & $22.17 \%$ & 1 & 0.398 & - & 0.864 & 2 & -6.829 & - & -0.121 & - & Distributive \\
\hline $\begin{array}{c}\text { DWS Aktien Strategie } \\
\text { Deutschland }\end{array}$ & $12.01 \%$ & 10 & 0.426 & 21 & 0.103 & - & -8.088 & - & -0.118 & - & Reinvestment \\
\hline $\begin{array}{l}\text { Deutsche AM Smart } \\
\text { Industrial Tech. }\end{array}$ & $13.81 \%$ & 6 & 0.400 & - & 0.256 & 17 & 2.937 & 14 & 0.128 & 7 & Distributive \\
\hline apo Medical Opportunities & $10.78 \%$ & 15 & 0.697 & 1 & 0.922 & 1 & -8.996 & - & 0.001 & - & Distributive \\
\hline NORDINTERNET & $14.20 \%$ & 5 & 0.503 & 11 & 0.230 & 18 & 2.937 & 28 & 0.128 & - & Reinvestment \\
\hline UniDeutschland XS & $12.81 \%$ & 9 & 0.589 & 5 & 0.143 & - & -15.992 & - & -0.133 & - & Reinvestment \\
\hline Deka-ConvergenceAktien & $3.34 \%$ & - & 0.116 & - & 0.042 & - & 11.645 & 4 & 0.219 & 4 & Distributive \\
\hline DWS Russia & $2.13 \%$ & - & 0.063 & - & 0.019 & - & 25.182 & 2 & 0.475 & 3 & Reinvestment \\
\hline Allianz Biotechnologie & $14.91 \%$ & 3 & 0.570 & 7 & 0.370 & 6 & -18.494 & - & -0.222 & - & Distributive \\
\hline Siemens Global Growth & $12.84 \%$ & 8 & 0.593 & 4 & 0.303 & 14 & 0.279 & 25 & -0.086 & 22 & Reinvestment \\
\hline Total average market & $4.90 \%$ & - & 0.246 & - & 0.067 & - & $-{ }^{*}$ & - & $-*$ & - & - \\
\hline Eugene Fama Benchmark & $3.99 \%$ & - & 0.247 & - & 0.043 & - & $-*$ & - & $-*$ & - & - \\
\hline
\end{tabular}

* $=$ not a passive benchmark performance measure.

Table 5. Descriptive statistics and risk-adjusted performance of the different fund types.

\begin{tabular}{cccccccccc}
\hline \multirow{2}{*}{ Type of mutual fund } & $\begin{array}{c}\text { Number of } \\
\text { funds }\end{array}$ & $\begin{array}{c}\text { Average } \\
\text { return }\end{array}$ & $\begin{array}{c}\text { Standard } \\
\text { deviation }\end{array}$ & Beta & $\begin{array}{c}\text { Sharpe } \\
\text { ratio }\end{array}$ & $\begin{array}{c}\text { Treynor } \\
\text { ratio }\end{array}$ & $\begin{array}{c}\text { Tracking } \\
\text { error }\end{array}$ & $\begin{array}{c}\text { Information } \\
\text { ratio }\end{array}$ & $\begin{array}{c}\text { Required cost of } \\
\text { equity }\end{array}$ \\
\hline Value & 37 & $5.05 \%$ & $20.94 \%$ & 0.674 & 0.254 & 0.097 & $1.16 \%$ & -5.796 & $3.171 \%$ \\
Growth & 28 & $7.26 \%$ & $23.13 \%$ & 0.659 & 0.323 & 0.017 & $1.32 \%$ & -7.125 & $3.524 \%$ \\
Income & 10 & $2.49 \%$ & $22.78 \%$ & 0.733 & 0.126 & 0.041 & $1.24 \%$ & -7.146 & $3.621 \%$ \\
Blue-chips & 26 & $4.98 \%$ & $22.97 \%$ & 0.794 & 0.229 & 0.074 & $1.18 \%$ & -7.327 & $2.904 \%$ \\
Industries & 20 & $6.23 \%$ & $24.76 \%$ & 0.462 & 0.297 & 0.198 & $1.59 \%$ & 1.941 & $5.300 \%$ \\
Other & 73 & $5.43 \%$ & $23.84 \%$ & 0.691 & 0.239 & 0.105 & $1.33 \%$ & -6.357 & $3.963 \%$ \\
Distributive & 122 & $5.10 \%$ & $22.91 \%$ & 0.702 & 0.237 & 0.102 & $1.26 \%$ & -6.531 & $3.560 \%$ \\
Reinvestment & 72 & $6.14 \%$ & $23.40 \%$ & 0.636 & 0.278 & 0.074 & $1.35 \%$ & -4.386 & $3.966 \%$ \\
Small \& mid cap & 14 & $9.02 \%$ & $23.75 \%$ & 0.564 & 0.377 & 0.009 & $1.42 \%$ & -7.641 & $4.032 \%$ \\
Mid \& large cap & 52 & $4.99 \%$ & $23.17 \%$ & 0.742 & 0.228 & 0.086 & $1.25 \%$ & -6.252 & $3.388 \%$ \\
All cap & 128 & $5.26 \%$ & $22.96 \%$ & 0.666 & 0.247 & 0.104 & $1.30 \%$ & -5.363 & $3.799 \%$ \\
TOTAL & 194 & $5.47 \%$ & $23.02 \%$ & 0.679 & 0.251 & 0.092 & $1.29 \%$ & -5.778 & $3.726 \%$ \\
\hline
\end{tabular}

Besides funds from the Income classification, all average returns were higher than the cost of equity. Yearly and monthly average returns on an absolute basis are also presented in Figure 2 and Figure 3.

Regarding other performance measures, the funds with focus on growth 


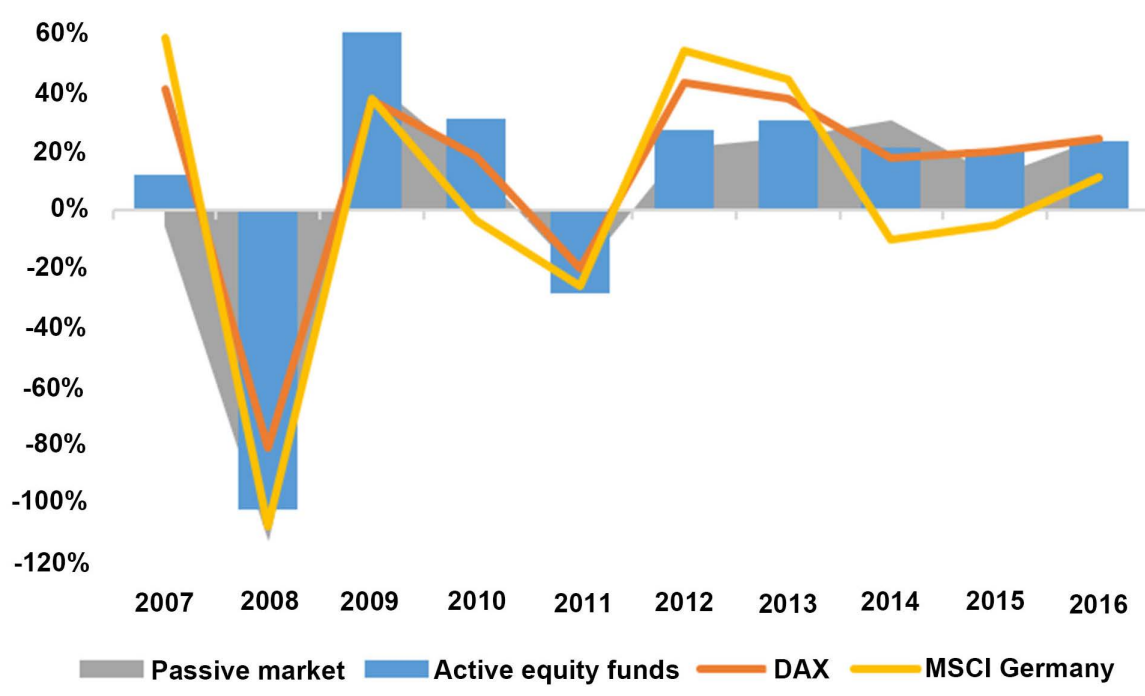

Figure 2. Yearly performance of active equity funds vs. benchmarks, 2007-2016. Notes: Figure 2 presents the yearly holding period return per year for the selected equity funds and the DAX, MSCI Germany and the passive equity funds representing the passive market. As can be seen from the graph, the trend of positive and negative performance is evident for all classes, with some outliers of outperformance and underperformance throughout the 10-year investment horizon, e.g. the equity funds outperformed all other classes in 2009 but underperformed the DAX and MSCI Germany in 2012.

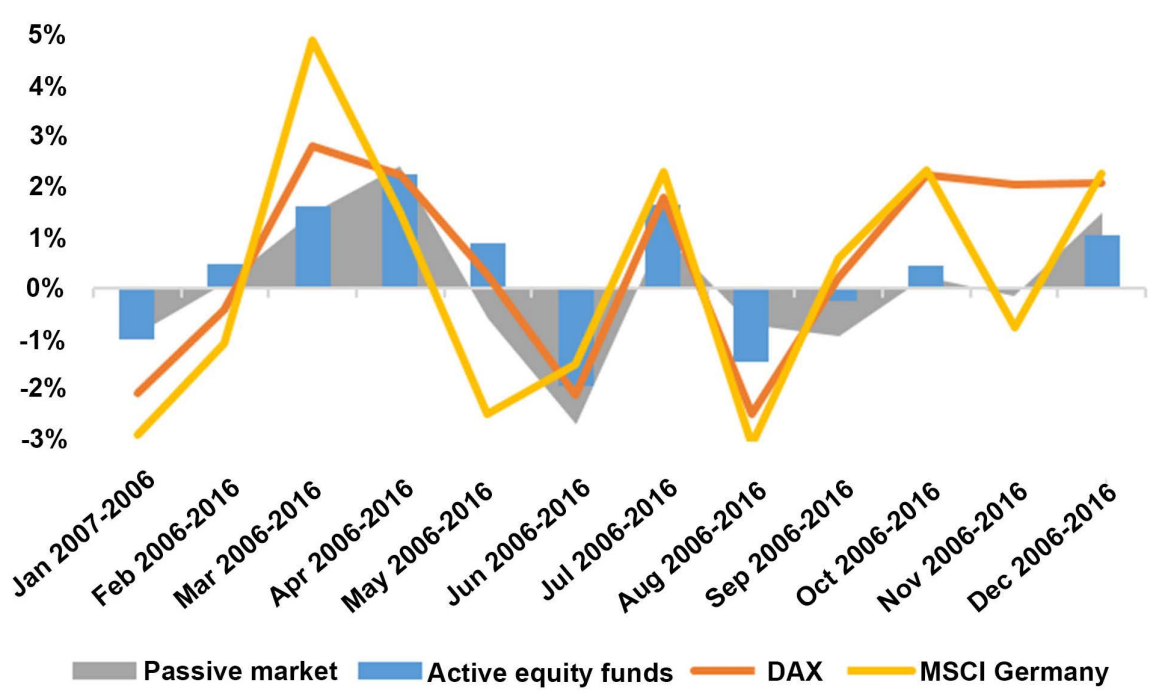

Figure 3. Monthly performance of active funds vs. benchmarks, 2007-2016. Notes: Figure 3 presents the average monthly holding period return during the 10-year investment horizon for the selected equity funds and the DAX, MSCI Germany and the passive equity funds representing the passive market. In this graph, obvious outliers are in the months March where the MSCI outperformed all other classes, but also underperformed in May. The month July showed an almost equity return for all classes.

shares generated the highest average returns. The Sharpe Ratio was also highest for this group. Second and third-highest performing groups were funds with an industry focus and value funds.

Further to mention is the significant better performance of Small \& Mid cap 
funds versus the Mid \& Large Cap group. The Small \& Mid Cap funds outperform clearly the average and even attained a higher average return and Sharpe ratio than the Growth funds. The Mid \& Large Caps on the other hand slightly under perform than the average.

A further observation from this table is the slightly significant difference in average returns between distributive and reinvestment funds. The results also suggest that funds with a focus on dividend shares (Group "Income") bear the highest risk compared to a relatively low mean return measure, whereas the value group exhibits the lowest risk. Important to note is that the Income funds clearly underperform the average of all funds.

Regression results showed different results compared to mean return and risk-adjusted returns. A series of cross-section return regression was conducted and all 194 funds were regressed with the benchmark index. Results demonstrate that merely one fund generated a statistically significant alpha at $a=0.1 \%$. The overall results of the linear regression therefore strongly suggest that the null hypothesis cannot be rejected; implying alpha is 0 in general for the active funds sample.

In addition, a ranking of the Top 25 funds in terms of Fama and French's Multifactor is presented in Table 6 . The funds are ranked in order of the 25 highest alpha generating fund based on the small cap and value stock outperformance theory. The return factor was estimated relative to the SMB (size), HML (valuation) and RM-RF (market) factors. The factors control for risk and return influences and are disclosed by Fama and French regularly. A risk-free rate of $0.26 \%$ was assumed. By using the inputs as variables for the expanded CAPM formula, an implied return is calculated. Although some of the 194 funds generate a positive alpha, none of them are statistically significant, as the basis of this model is not regression of historical performance. The mean of all active funds implied return underperforms the market return by $120 \mathrm{bp}$, leading to a further indication that the null hypothesis cannot be rejected.

\section{Conclusion}

A sample of actively managed funds has been examined to assess if active funds create value relative to the passive market segment on the German market. As the results have shown, different measures of performance paint different pictures of results. The arithmetic average annual return of the sample is $5.47 \%$, compared to $4.90 \%$ of benchmark returns. The risk-adjusting performance measure results show that active funds perform slightly better, exhibiting a Sharpe Ratio of 0.251 compared to 0.241 of the market. Evidence shows that gross of costs, there are indeed several active funds which outperform the benchmark. Especially the risk-adjusting performance indicates that the active sector outperforms the benchmark. When accounting for costs however, it becomes evident that the value of alpha that was generated through superior average returns of active funds is offset by the expenses. The regression results indicate similar inferior results. There is nearly no significant value which could lead 
Table 6. Performance measure of multifactor model.

\begin{tabular}{|c|c|c|c|c|c|c|c|c|c|c|c|c|}
\hline \multirow[b]{2}{*}{ Mutual fund name } & \multicolumn{3}{|c|}{ Market-factor } & \multicolumn{3}{|c|}{ Size-factor } & \multicolumn{3}{|c|}{ Relative valuation } & \multirow{2}{*}{$\begin{array}{l}\text { RFR-factor } \\
\text { RF mean }\end{array}$} & \multicolumn{2}{|c|}{ CAPM } \\
\hline & Mkt-RF & Mean & $\begin{array}{c}\text { Mkt } \\
\text { premium }\end{array}$ & SMB & Mean & $\begin{array}{c}\text { SBM } \\
\text { premium }\end{array}$ & HML & Mean & $\begin{array}{c}\text { HML } \\
\text { premium }\end{array}$ & & Alpha & Rank \\
\hline $\begin{array}{l}\text { DKO-Lux-Aktien } \\
\text { Deutschland }\end{array}$ & 0.5879 & $0.02 \%$ & $2.51 \%$ & 2.050 & 0.000 & $4.5 \%$ & 0.45 & $0.00 \%$ & 0.03040 & $0.26 \%$ & $12.40 \%$ & 1 \\
\hline GR Dynamik & 0.5353 & $0.02 \%$ & $2.51 \%$ & 1.783 & 0.000 & $4.5 \%$ & 0.26 & $0.00 \%$ & 0.03040 & $0.26 \%$ & $10.48 \%$ & 2 \\
\hline GRNoah & 0.436 & $0.02 \%$ & $2.51 \%$ & 1.557 & 0.000 & $4.5 \%$ & 0.29 & $0.00 \%$ & 0.03040 & $0.26 \%$ & $9.29 \%$ & 3 \\
\hline Istanbul Equity Fund & 0.4416 & $0.02 \%$ & $2.51 \%$ & 1.510 & 0.000 & $4.5 \%$ & 0.24 & $0.00 \%$ & 0.03040 & $0.26 \%$ & $8.95 \%$ & 4 \\
\hline GOEAST-INVEST & 0.9567 & $0.02 \%$ & $2.51 \%$ & 0.984 & 0.000 & $4.5 \%$ & 0.56 & $0.00 \%$ & 0.03040 & $0.26 \%$ & $8.84 \%$ & 5 \\
\hline DWSOsteuropa & 0.98 & $0.02 \%$ & $2.51 \%$ & 0.698 & 0.000 & $4.5 \%$ & 0.56 & $0.00 \%$ & 0.03040 & $0.26 \%$ & $7.58 \%$ & 6 \\
\hline Deka-Convergence Aktien & 1.0142 & $0.02 \%$ & $2.51 \%$ & 0.768 & 0.000 & $4.5 \%$ & 0.36 & $0.00 \%$ & 0.03040 & $0.26 \%$ & $7.39 \%$ & 7 \\
\hline $\begin{array}{c}\text { Deutsche AM Smart } \\
\text { Industrial Technologies }\end{array}$ & 0.6824 & $0.02 \%$ & $2.51 \%$ & 0.887 & 0.000 & $4.5 \%$ & 0.37 & $0.00 \%$ & 0.03040 & $0.26 \%$ & $7.12 \%$ & 8 \\
\hline Monega Innovation & 0.9077 & $0.02 \%$ & $2.51 \%$ & 0.836 & 0.000 & $4.5 \%$ & 0.24 & $0.00 \%$ & 0.03040 & $0.26 \%$ & $7.07 \%$ & 9 \\
\hline Deka Umweltinvest & 0.811 & $0.02 \%$ & $2.51 \%$ & 1.034 & 0.000 & $4.5 \%$ & 0.02 & $0.00 \%$ & 0.03040 & $0.26 \%$ & $7.06 \%$ & 10 \\
\hline $\begin{array}{l}\text { Allianz Emerging Markets } \\
\text { Equity Dividend }\end{array}$ & 0.9833 & $0.02 \%$ & $2.51 \%$ & 0.853 & 0.000 & $4.5 \%$ & 0.12 & $0.00 \%$ & 0.03040 & $0.26 \%$ & $6.96 \%$ & 11 \\
\hline $\begin{array}{c}\text { DWS Global Natural } \\
\text { Resources Equity Typ O }\end{array}$ & 1.0125 & $0.02 \%$ & $2.51 \%$ & 0.846 & 0.000 & $4.5 \%$ & 0.10 & $0.00 \%$ & 0.03040 & $0.26 \%$ & $6.94 \%$ & 12 \\
\hline Deutschland-INVEST & 0.7431 & $0.02 \%$ & $2.51 \%$ & 0.890 & 0.000 & $4.5 \%$ & 0.23 & $0.00 \%$ & 0.03040 & $0.26 \%$ & $6.87 \%$ & 13 \\
\hline FVB-Deutscher Aktienfonds & 0.7147 & $0.02 \%$ & $2.51 \%$ & 0.873 & 0.000 & $4.5 \%$ & 0.27 & $0.00 \%$ & 0.03040 & $0.26 \%$ & $6.84 \%$ & 14 \\
\hline Uni Asia & 0.78 & $0.02 \%$ & $2.51 \%$ & 1.016 & 0.000 & $4.5 \%$ & -0.02 & $0.00 \%$ & 0.03040 & $0.26 \%$ & $6.77 \%$ & 15 \\
\hline $\begin{array}{l}\text { DKO-Lux-Aktien } \\
\text { Nordamerika }\end{array}$ & 0.4518 & $0.02 \%$ & $2.51 \%$ & 1.066 & 0.000 & $4.5 \%$ & 0.14 & $0.00 \%$ & 0.03040 & $0.26 \%$ & $6.66 \%$ & 16 \\
\hline DWS Financials & 0.9767 & $0.02 \%$ & $2.51 \%$ & 0.385 & 0.000 & $4.5 \%$ & 0.69 & $0.00 \%$ & 0.03040 & $0.26 \%$ & $6.54 \%$ & 17 \\
\hline Allianz Adiverba & 0.8656 & $0.02 \%$ & $2.51 \%$ & 0.287 & 0.000 & $4.5 \%$ & 0.90 & $0.00 \%$ & 0.03040 & $0.26 \%$ & $6.48 \%$ & 18 \\
\hline Postbank Megatrend & 0.7612 & $0.02 \%$ & $2.51 \%$ & 0.981 & 0.000 & $4.5 \%$ & -0.06 & $0.00 \%$ & 0.03040 & $0.26 \%$ & $6.43 \%$ & 19 \\
\hline $\begin{array}{l}\text { SEB European Equity } \\
\text { Small Caps }\end{array}$ & 0.462 & $0.02 \%$ & $2.51 \%$ & 1.050 & 0.000 & $4.5 \%$ & 0.07 & $0.00 \%$ & 0.03040 & $0.26 \%$ & $6.41 \%$ & 20 \\
\hline DWS Merkur Fonds1 & 0.8476 & $0.02 \%$ & $2.51 \%$ & 0.661 & 0.000 & $4.5 \%$ & 0.31 & $0.00 \%$ & 0.03040 & $0.26 \%$ & $6.32 \%$ & 21 \\
\hline $\begin{array}{c}\text { Deutsche ESG } \\
\text { European Equities }\end{array}$ & 0.7626 & $0.02 \%$ & $2.51 \%$ & 0.793 & 0.000 & $4.5 \%$ & 0.16 & $0.00 \%$ & 0.03040 & $0.26 \%$ & $6.26 \%$ & 22 \\
\hline Ampega Global Aktienfonds & 0.3224 & $0.02 \%$ & $2.51 \%$ & 1.046 & 0.000 & $4.5 \%$ & 0.11 & $0.00 \%$ & 0.03040 & $0.26 \%$ & $6.16 \%$ & 23 \\
\hline Top Portfolio-INVEST & 0.4768 & $0.02 \%$ & $2.51 \%$ & 0.840 & 0.000 & $4.5 \%$ & 0.28 & $0.00 \%$ & 0.03040 & $0.26 \%$ & $6.13 \%$ & 24 \\
\hline $\begin{array}{l}\text { LINGOHR-ASIEN- } \\
\text { SYSTEMATIC-LBB- } \\
\text { INVEST }\end{array}$ & 0.6773 & $0.02 \%$ & $2.51 \%$ & 0.897 & 0.000 & $4.5 \%$ & 0.03 & $0.00 \%$ & 0.03040 & $0.26 \%$ & $6.11 \%$ & 25 \\
\hline
\end{tabular}

to the determination that alpha is different than 0 , hence the null hypothesis is not rejected in this study. Since two different benchmark systems have been applied, the well-tried issue of benchmark selection emerges. Even when using several benchmarks for comparison, this does not conclude that the whole market is represented through one index. Though not presented in this study, but the application of a different benchmark in the analysis model logically would 
result in different results. This is a strong indication that active funds do create value, but it depends on where the value threshold begins set by the chosen benchmark and to which level the expenses offset abnormal returns.

In addition, the incongruent empirical findings raise the need of a discussion of the literature review. Although most researchers tend to agree though that active investment funds as a group underperform compared to the market portfolio, there is sound and selected evidence that active funds can indeed outperform the market. These discrepancies can be allocated to different methodology structures, investment time horizons and starting points, different performance measurements, costs and benchmark selection.

Investors still tend to invest in the active fund market despite the predominant evidence of inferior performance, and the driver could be that investors are indeed aware of the empirical evidence and are trying to identify (or have identified) the specific active managers who do outperform the market regularly. In addition, funds are priced at NAV, and this value does not represent the stock-picking skills of management. Hence, sophisticated investors recognize that previous abnormal returns can predict future abnormal returns, but the persistency of stock-picking skill is not represented in the NAV (Gruber, 1996). A further possible reason suggested is that investors have recognized the positive correlation between active managers' performance and their respective management fees (Fama \& French, 2010).

\section{Conflicts of Interest}

The authors declare no conflicts of interest regarding the publication of this paper.

\section{References}

Basu, S. (1977). Investment Performance of Common Stocks in Relation to Their Price-Earnings Ratios: A Test of the Efficient Market Hypothesis. The Journal of Finance, 32, 663-682. https://doi.org/10.2307/2326304

Blanchett, D. M., \& Israelsen, C. L. (2007). Spotlighting Common Methodological Biases in Active vs. Passive Studies. Journal of Financial Planning, 20, 64-74.

Brinson, G. P., Hood, L. R., \& Beebower, G. L. (1995). Determinants of Portfolio Performance. Financial Analysts Journal, 51, 133-138. https://doi.org/10.2469/faj.v51.n1.1869

Brown, S. J., Goetzmann, W. N., Ibbotson, R. G., \& Ross, S. A. (1992). Survivorship Bias in Performance Studies. The Review of Financial Studies, 5, 553-580. https://doi.org/10.1093/rfs/5.4.553

Carhart, M. M. (1997). On Persistence in Mutual Fund Performance. The Journal of Finance, 52, 57-82. https://doi.org/10.2307/2329556

Chan, K. C., Gup, B. E., \& Pan, M.-S. (1997). International Stock Market Efficiency and Integration: A Study of Eighteen Nations. Journal of Business Finance \& Accounting, 24, 803-813. https://doi.org/10.1111/1468-5957.00134

De Bondt, W. F. M., \& Thaler, R. (1985). Does the Stock Market Overreact? The Journal of Finance, 40, 793-805. https://doi.org/10.1111/j.1540-6261.1985.tb05004.x

Elton, J. E., Gruber, M. J., \& Blake, C. R. (1996). Survivorship Bias and Mutual Fund Per- 
formance. The Review of Financial Studies, 9, 1097-1120.

https://doi.org/10.1093/rfs/9.4.1097

Fama, E. F. (1970). Efficient Capital Markets: A Review of Theory and Empirical Work. The Journal of Finance, 25, 383-417. https://doi.org/10.2307/2325486

Fama, E. F., \& French, K. R. (2010). Luck versus Skill in the Cross-Section of Mutual Fund Returns. The Journal of Finance, 65, 1915-1947. https://doi.org/10.1111/j.1540-6261.2010.01598.x

Fuller, R. J., Han, B., \& Tung, Y. (2010). Thinking about Indices and "Passive" versus Active Management. The Journal of Portfolio Management, 36, 35-47. https://doi.org/10.3905/jpm.2010.36.4.035

Grinblatt, M., \& Titman, S. (1989). Mutual Fund Performance: An Analysis of Quarterly Portfolio Holdings. The Journal of Business, 62, 393-416. https://doi.org/10.1086/296468

Grinblatt, M., \& Titman, S. (1992). The Persistence of Mutual Fund Performance. The Journal of Finance, 47, 1977-1984. https://doi.org/10.2307/2329005

Grossman, S. J., \& Stiglitz, J. E. (1980). On the Impossibility of Informationally Efficient Markets. The American Economic Review, 70, 393-408.

Gruber, M. J. (1996). Another Puzzle: The Growth in Actively Managed Mutual Funds. The Journal of Finance, 51, 783-810. https://doi.org/10.1111/j.1540-6261.1996.tb02707.x

Hendricks, D., Patel, J., \& Zeckhauser, R. (1993). Hot Hands in Mutual Funds: Short-Run Persistence of Relative Performance, 1974-1988. The Journal of Finance, 48, 93-130. https://doi.org/10.1111/j.1540-6261.1993.tb04703.x

Investmentfonds-Datenbank. https://portal.mvp.bafin.de/database/FondsInfo

Jensen, M. C. (1968). The Performance of Mutual Funds in the Period 1945-1964. The Journal of Finance, 23, 389-416. https://doi.org/10.1111/j.1540-6261.1968.tb00815.x

Lim, T. C., Lim, X. Y., \& Zhai, R. (2012). History of the Efficient Market Hypothesis. International Journal of Management Sciences and Business Research, 1, 26-33.

Malkiel, B. G. (1995). Returns from Investing in Equity Mutual Funds 1971 to 1991. The Journal of Finance, 50, 549-572. https://doi.org/10.2307/2329419

Malkiel, B. G. (2003). Passive Investment Strategies and Efficient Markets. European Financial Management, 9, 1-10. https://doi.org/10.1111/1468-036X.00205

Malkiel, B. G. (2005). Reflections on the Efficient Market Hypothesis: 30 Years Later. The Financial Review, 40, 1-9. https://doi.org/10.1111/j.0732-8516.2005.00090.x

Pástor, L., \& Stambaugh, R. (2002). Mutual Fund Performance and Seemingly Unrelated Assets. Journal of Financial Economics, 63, 315-349.

https://doi.org/10.1016/S0304-405X(02)00064-8

Philips, C. B., Kinniry, F. M. Jr., \& Walker, D. (2014). The Active-Passive Debate: Market Cyclicality and Leadership Volatility.

https://personal.vanguard.com/pdf/ISGACT.pdf

Read, C. (2013). The Efficient Market Hypothesists: Bachelier, Samuelson, Fama, Ross, Tobin and Shiller. Basingstoke: Palgrave Macmillan. https://doi.org/10.1057/9781137292216

Schädler, T. (2018). Measuring Irrationality in Financial Markets. Archives of Business Research, 6, 252-259. https://doi.org/10.14738/abr.612.5876

Sewell, M. (2011). History of the Efficient Market Hypothesis (Research Note No. RN/11/ 04). London: UCL Department of Computer Science. 
http://www.cs.ucl.ac.uk/fileadmin/UCL-CS/images/Research_Student_Information/RN 11_04.pdf

Sharpe, W. F. (1991). The Arithmetic of Active Management. Financial Analysts Journal, 47, 7-9. https://doi.org/10.2469/faj.v47.n1.7

Shukla, R. (2004). The Value of Active Portfolio Management. Journal of Economics and Business, 56, 331-346. https://doi.org/10.1016/j.jeconbus.2004.01.002

Wermers, R. (2000). Mutual Fund Performance: An Empirical Decomposition into Stock-Picking Talent, Style, Transactions Costs, and Expenses. The Journal of Finance, 55, 1655-1695. https://doi.org/10.1111/0022-1082.00263

Womack, K. L. (1996). Do Brokerage Analysts' Recommendations Have Investment Value? The Journal of Finance, 51, 137-167. https://doi.org/10.2307/2329305 